\title{
Image Improvement of The State Islamic University (UIN) Alauddin Makassar through The Satisfaction and Trust of Stakeholder on Graduate Quality
}

\author{
Murtiadi Awaluddin \\ The State Islamic University (UIN) Alauddin Makassar, Indonesia \\ yadi_awal@yahoo.com
}

\begin{abstract}
This study aims to determine and analyze the influence of UIN Alauddin Makassar graduate quality to stakeholder satisfaction, stakeholder trust and image of UIN Alauddin Makassar either directly or indirectly. This study categorized in exploratory research. This research included in the descriptive research. The population of this research is all stakeholders in Makassar City. The sampling technique used in this research is purposive sampling. The sample criterion used is a private banking company that employs UIN Alauddin Makassar graduates. The sample size uses maximum likelihood (ML). The number of samples in this study is 100 respondents. In this study, the techniques used include (1) questionnaire; (2) observation; (3) interviews and (4) documentation. The method of analysis used in this research is structural equation modelling (SEM) analysis. The conclusion of this research are: (1) the quality of UIN Alauddin Makassar graduates has a positive and significant impact on stakeholder satisfaction, stakeholder trust and image of UIN Alauddin Makassar; (2) stakeholder satisfaction has a positive and significant impact on stakeholder trust and image of UIN Alauddin Makassar and (3) stakeholder trust have positive and significant impact on UIN Alauddin Makassar image.
\end{abstract}

Keywords: Graduate quality, Stakeholder satisfaction, Stakeholder trust and image

\section{Introduction}

In the era of ASEAN Economic Community (MEA) today, it cannot be denied that among universities in Indonesia there is a massification marked by the proliferation of new institutions of higher education. The annual report data of the Ministry of Research, Technology and Higher Education dated September 1, 2016, states that there are 3,940 private universities active in Indonesia consisting of 144 polytechnics, 1,021 academies, 6 community colleges, 466 universities, institutes 99 and high schools amounted to 2,348. While for state universities amounted to 372 consisting of 86 academics, 99 polytechnics, 75 universities, institutes amounted to 33, 75 high schools, and community colleges amounted to 3. Compared to 2010 Number of Universities in Indonesia only amounted to 3,070 Number of Universities: 465, Number of Institutes: 55, Number of Colleges: 1,345, Number of Academicians: 1,037, Number of Polytechnic: 168, Number of Highest PTs: High School: 1,345 and Institut amounted to 55. 
The high growth of universities brought colleges (PT) in the competition orientation that is not only at the national level, but the orientation of universities has also now shifted to the competition among universities globally.

The existence of universities in the face of such competition makes almost all colleges offer superior courses, compete offers facilities that are all sophisticated IT-based, the study period is relatively more flexible, to the stage how to maintain the quality of graduates to create a good image in the eyes of stakeholders. The image or reputation of the institution reflects the institution's philosophy from the particular institution or group concerned with the company. The image is formed based on the impression, the knowledge experienced by a person to something so that finally build a mental attitude, mental attitude is later used as a consideration to make decisions. The image is considered to represent the totality of one's knowledge of something (Alma, 2007). Meanwhile, according to Rahayu (2009), the image or reputation of universities as one of the factors in improving competitiveness is one of the key elements of intangible resources that will be the source of the creation of a sustainable competitive advantage condition of a company. The image or reputation formed is obtained through a series of accumulated abilities and experiences so that the university has the best performance for stakeholders. From these findings and theories, it can be concluded that the good image of the institution can be established through a series of stakeholder experiences on the performance of the alumni so that the stakeholders' satisfaction and trust in the institution will be established.

One of the institutions that always get the spotlight in the eyes of society and stakeholders is the State Islamic University (UIN) Alauddin Makassar, so far the image built in the society is an institution with a good lecture building, a civilized campus, and also a broad religious knowledge. Also, according to Rector (UIN) Alauddin Makassar, in his empirical experience in visiting the place of KKN, stated that UIN Alauddin Makassar students have a positive image in the middle of society, especially in areas that have been occupied by students in Real Work Lecture (Uin-Alauddin.ac.id, 2017). In addition to the positive image in circulation, there are also some student actions that like the demo, boycotting the street and the behavior of students who do not reflect the nature of Islam which is also a spate of negative responses about (UIN) Alauddin Makassar itself both in the eyes of the community and stakeholders give a negative impression, so it is feared to affect stakeholder trust on the quality of alumni (UIN) alumni of Makassar. Based on this phenomenon and because many students have graduated from UIN Alauddin and have worked in various fields, it is deemed necessary to study about how to build alumni image (UIN) Alauddin Makassar through the satisfaction and trust of stakeholders on the quality of graduates. This study aims to determine and analyze the influence of UIN Alauddin Makassar graduate quality to stakeholder satisfaction, stakeholder trust and image of UIN Alauddin Makassar either directly or indirectly.

\section{Literature Review}

\section{Study on the Quality of University Graduates}

University is an educational institution that gave birth to human resources in the form of graduates who are expected to be ready to be absorbed by the community as its users. Alumni/graduates are the spearheads of accountability of a university in the eyes of society. Their existence and activities will bring the university's attributes, advantages, uniqueness and lack of university will not be separated from the alumni. Alumni that are well absorbed by the 
market, whether they are entrepreneurs or working with others, can be the basis of whether the existence of the institution (course/ department/faculty) will still be maintained or not.

Tom and Elmer, (1994) stated that alumni make substantial contributions from the donation side and their attitudes in the field, both in society and work environment. According to Goetsch and Davis (in Tjiptono, 2005), quality is defined as the dynamic conditions associated with products, services, human resources, processes, and environments that meet or exceed expectations. Quality can also be defined as the overall characteristics and nature of goods and services that affect the ability to meet both stated and implied needs (Kotler, 2009). Lovelock (in Laksana, 2008) defines quality as the expected quality level and diversity control in achieving that quality to meet consumer needs. So the quality of graduates, in this case, is the quality of graduate performance as the level of quality expected to meet the needs of consumers.

\section{Study of Stakeholder Satisfaction}

Stakeholders are individuals, groups of people, communities or communities either as a whole or as a part that has relationships and interests to the company. Individuals, groups, and communities and communities can be regarded as stakeholders if they have characteristics as revealed by Budimanta et al. (in Chariri and Ghozali, 2007) that have the power, legitimacy, and interests of the company.

Nowadays, with many institutions that graduate alumni with the same study program, it is easy for stakeholders to select and select the alumni that will be employed, so the institution must be extra hard to design in such a way that various aspects for the alumni to give satisfaction to stakeholders where they work. According to Evans and Lindsay (2002), satisfaction is meeting or exceeding customer satisfaction begins with hiring the right person. Customer satisfaction can only be achieved if the company hires the right people. Another opinion Customer Satisfaction is a person's feelings of pleasure or disappointment after comparing perceived performance or results compared to expectations (Kotler and Keller, 2007).

\section{Review of Beliefs}

Trust is an individual attitude that refers to consumer confidence in the quality and reliability of the services it receives (Garbarino and Johnson in Kusmayadi, 2007). According to David A. Aaker (2004), customer confidence in the company is an important attribute in developing a company. An institution will be credible if it can provide benefits to its graduate user stakeholders as well as good behaviour from its employees. Consumer belief is all the knowledge possessed by consumers and all consumer conclusions about the object, its attributes and its benefits (Mowen and Minor, 2002).

1. Objects can be products, people, companies, and everything that someone has trust and attitude.

2. Attributes are characteristics or features that may or may not belong to the object.

3. Benefits are positive results given attributes to consumers.

According to Gurviez and Korchia (2003), several things can be identified from the variable of trust. First, trust and commitment are the most important and strategic variables to maintain longterm relationships with industry partners and businesses. Second, an explanation of the variables 
of trust and commitment in the relationship between the company and the consumer, providing supplements to economic theory, especially about transaction costs. Third, the most significant difficulty in conceptualizing trust is on cognitive and affective grounds. Some factors such as brand, past experience and so on can affect consumer confidence.

\section{Conceptual Framework}

In building a positive image, UIN Alauddin Makassar can start from improving the quality performance of graduates who work on stakeholders. The resulting performance will affect stakeholder satisfaction so that it impacts stakeholder trust. If stakeholders believe it will give a positive image of the institution. Moreover, the development is the alumni UIN Alauddin Makassar will get a better chance in the world of work competition. Based on the description above, then can be made a conceptual framework as follows:

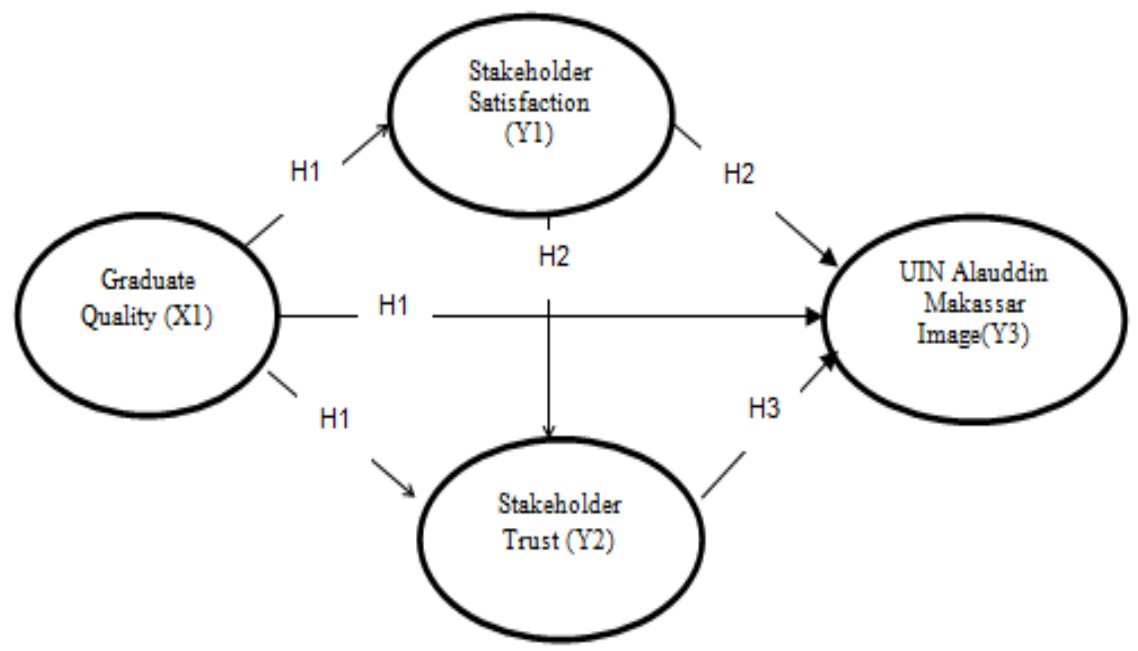

Figure 1. Conceptual Framework Scheme

\section{Hypothesis}

Based on the above theoretical studies, the hypotheses in this study are as follows:

H1: The quality of UIN Alauddin Makassar graduates has a positive and significant impact on stakeholder satisfaction, stakeholder trust and image of UIN Alauddin Makassar.

$\mathrm{H} 2$ : Stakeholder satisfaction has a positive and significant impact on stakeholder trust and image of UIN Alauddin Makassar.

H3: The stakeholder trust has a positive and significant impact on the image of UIN Alauddin Makassar.

\section{Research Methods}

\section{Research Design}

This study is categorized in exploratory research which only tested hypotheses developed from theoretical studies. Further data collected and analyzed in this research used survey method approach. Based on the type of research, this research is a research that explains the causal relationship between the variables, or the so-called explanatory research (explanatory research) is research to determine and explain the influence between variables that exist and followed by testing the hypothesis. Also, this research is included in the descriptive research, because it provides the descriptive explanation of the variables to be studied. 


\section{Population and Sample Research}

The population of this research is all stakeholders in Makassar City. The sampling technique used in this research is purposive sampling that is taking samples based on certain considerations or criteria according to the purpose of research (Cooper and Emory, 1997). As sample criterion used is a private banking company that employs UIN Alauddin Makassar graduate. The sample size plays an important role in estimating and interpreting the results of Structural Modeling (SEM) analysis, as it provides a basis for estimating error sampling errors (Ferdinand, 2002 and Ghozali, 2004). According to Ferdinand (2002), Ghozali (2004), Ghozali (2008), Solimun and Rinaldo (2009), sample sizes between 100-200 samples can be recommended for maximum liking (ML) estimates.

With estimation models using maximum likelihood (ML), data required the minimum of 100 samples (Ferdinand, 2002; Ghozali, 2004; Ghozali, 2008; Solimun and Rinaldo, 2009). According to Ferdinand (2002) and Ferdinand (2006), SEM analysis requires samples of at least 5 times the number of indicator variables or estimated parameters used by Ferdinand (2002) and Solimun and Rinaldo (2009) provides guidance on determining sample size equal to 5 - 10 times the manifest variable of all latent variables.

In this study using 5 latent variables were for variable Quality graduates $\left(\mathrm{X}_{1}\right)$ consists of 7 indicators. The stakeholder satisfaction variable $\left(\mathrm{Y}_{1}\right)$ consists of 4 indicators. The stakeholder trust variable $\left(\mathrm{Y}_{2}\right)$ consists of 5 indicators. Image Variable $\left(\mathrm{Y}_{3}\right)$ consists of 4 indicators. So the total indicator of the latent variable is 24 . So the number of samples in this study is $5 \times 20=100$ respondents

\section{Types and Data Sources}

1. Data Type. In this research, the type of data used is qualitative and quantitative, i.e., data obtained in the form of interviews and the numbers (numeric) of the questionnaire results.

2. Data Source. Sources of data used in this study are primary data, i.e., data obtained directly from respondents also in the form of secondary in the form of written form of documents documents of private banking stakeholders in the city of Makassar and other written information that has a direct link to the problems studied.

\section{Data collection techniques}

In this study the techniques used include:

1. Questionnaire. Questionnaires are arranged in the form of questions of written questions given to respondents.

2. Observation. Observation is done by doing the direct observation to the research location by looking at various activities undertaken by the respondent.

3. Interview. Interviews used are in-depth interviews or unstructured interviews.

4. Documentation. The required documentation is written or unwritten documents that show or describe important data and information related to the research.

\section{Analysis Method}

The analysis method used in this research is structural equation modelling (SEM) analysis to know the causal relationship between latent variables contained in the structural equation. The 
steps that must be taken in making a complete modeling by Hair et al. (2006) are the development of models based on the theory, the development of path diagrams, changing the path diagram into equations, selecting input matrices, choosing identification problems, choosing goodness of fit and interpretation and modification of the model. To determine the suitability of the measurement model that is formed, it is necessary to test the suitability of the model. There are several indexes of suitability model that can be used to measure fit or not a model that is:

\section{Chi-Square Statistic (CSS)}

The Chi-Square values showed the existence of deviations between the covariance matrix and fitted covariance matrix samples. The Chi-Square value will only be valid if the assumption of data normality is met and the large sample size (Ghozali, 2008). The value of Chi-Square for zero indicates that the model has a perfect fit (perfect fit).

\section{The Root Mean Square Error of Approximation (RMSEA)}

RMSEA is the most informative indicator (Ghozali, 2009). RMSEA measures the storage of parameter values in a model with its population covariance matrix (Ghozali, 2008). The RMSEA value $<0.05$ identifies the fit model. Values ranging from 0.05 to 0.08 suggest that the model has a reasonable error estimate, whereas RMSEA ranging from 0.08 to 0.01 suggests that the model has adequate fit (mediocre) (Ghozali, 2008).

\section{The goodness of Fit Indices (GFI)}

GFI is a measure of the determination of models in analyzing observed covariance matrices. This GFI value should range between 0 and 1 GFI values greater than 0.9 indicating fit for a good model (Ghozali, 2009).

\section{Adjusted Goodness of Fit Indices (AGFI)}

AGFI is the same as GFI but has adjusted the influence of degrees of freedom on a model. Just like GFI, an AGFI value of one means having perfect fit AGFI value of 1 means the model has a perfect fit. While the model is fit, that has an AGFI value greater than 0.90 (Ghozali, 2008).

\section{Comparative Fit Indices (CFI)}

CFI is an index whose magnitude is not influenced by the sample size because it is excellent for measuring the acceptability of a model. This index falls within the range and 1 and is derived from the comparison between the hypothesized model and the independence model. According to Bentler (in Ghozali, 2008) stated that a model is said to be fit if it has a CFI value greater than 0.90 .

The analytical tool used is with the help of reduced form and application program statistics AMOS ver. 22.0 and SPSS ver 19.0.

Operational Definition of Variables

For the variables covered in this study to give the same meaning and can be measured, then made the operational definition of each variable as follows:

1. Quality of graduates (X1) is the quality of graduate performance as the level of quality expected to meet the needs of stakeholders. Indicators used are: (1) communication skills; (2) organizational skills; (3) leadership; (4) logic; (5) effort; (6) group skills; and (7) ethics. 
2. Stakeholder satisfaction (Y1) is the feelings of pleasure or disappointment of stakeholders after comparing the performance of graduates or perceived results compared with expectations. The indicators used are (1) feelings of pleasure; (2) evaluation; (3) the performance of graduates; (4) confirmation of expectations.

3. Trust stakeholders (Y2) is a stakeholder attitude that refers to the belief in the quality and reliability of UIN Alauddin Makassar graduate's performance received. The indicators used are:(1) benevolence; (2) integrity; (3) competence; (4) willingness to depend; (5) subjective probability of depending.

4. Image (Y3) is impression, impression, feeling or conception that exist on stakeholder concerning UIN Alauddin Makassar graduate. The indicators used are (1) advertising; (2) public relations; (3) physical image; and (4) actual experience.

\section{Results}

\section{Frequency Distribution}

Based on the results of the calculation of each respondent's answer variables can be interpreted as follows: 1) The average respondents' answers to the quality of graduates are at score 3.97, so it is in either category. 2) The average respondent's answer to stakeholder satisfaction is at score 4.08 so that stakeholder satisfaction on graduates are in an outstanding category.3) The average of respondent's answer to stakeholder trust is at score 3.92 so stakeholder trust to graduate is in a good category. 4) The average respondent's response to UIN Alauddin's image is at score 3.79 so that UIN Alauddin's image from the standpoint of stakeholder is in a good category. The result of the calculation in the form of the scheme can be seen in Figure 2 below:

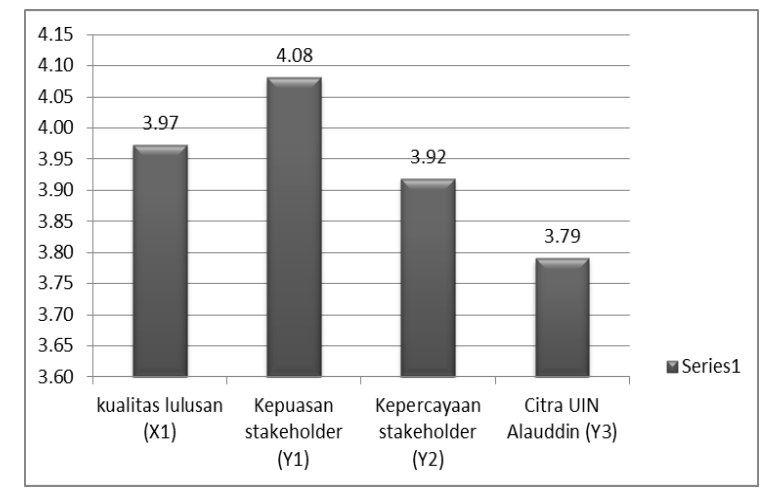

Figure 2. Recapitulation of calculation of respondent's answer

\section{Overall Model Testing}

Structural model testing of all the latent variables (construct) consisting of the quality of graduates as independent and subsequent stakeholder satisfaction, stakeholder trust and image of UIN Alauddin as the dependent variable is connected by using the goodness of fit test. Based on the overall model, the evaluation will be done as seen in Table 1 below: 
Table 1. Computational Results Criteria Goodness Of Fit Indices Complete Model Testing

\begin{tabular}{|l|l|c|c|}
\hline \multicolumn{1}{|c|}{ Criteria } & \multicolumn{1}{c|}{ Cut-off value } & Computation result & Information \\
\hline Chi-Square & Expectedlower & 166.872 & Fit \\
\hline Rel.Chi-Square & $\leq 2,00$ & 1.084 & Fit \\
\hline Sig. Probability & $\geq 0,05$ & 0,226 & Fit \\
\hline RMSEA & $\leq 0,08$ & 0.029 & Fit \\
\hline CFI & $\geq 0,90$ & 0.977 & Fit \\
\hline TLI & $\geq 0,90$ & 0.971 & Fit \\
\hline NFI & $\geq 0,90$ & 0.775 & Less Fit \\
\hline IFI & $\geq 0,90$ & 0.951 & Fit \\
\hline
\end{tabular}

Source: Computational Result

Based on the test results as shown in the above table, it appears that the value of Goodness of Fit Indices for all criteria in general in the category fit except NFI. Thus the model is said to be overall quite good. According to Wijanto (2007), there are several measures of the fit model in SEM, and the appraisal of model conformity is assessed based on how many model sizes can be satisfied by the research model. The more match target values of the Goodness of Fit measure are met by the model, the better the research model.

Analysis and Testing Structural Models Graduates Quality Impact on Stakeholder Satisfaction, Stakeholder Trust and Image of UIN Alauddin Makassar

To facilitate in analyzing the functional relationship between variables then the coefficient value is arranged in Table form as shown in Table 2 below:

Table 2. Inter-variable Functional Relationships

\begin{tabular}{|c|c|c|c|c|c|c|c|}
\hline Influencing Variables & Variable Influenced & Direction & Estimation & S.E & T Value & Prob & Information \\
\hline \multirow{3}{*}{ Graduate_Quality $\left(X_{1}\right)$} & Stakeholder_Satisfaction_y1 & $X_{1} \rightarrow Y_{1}$ & 0.677 & 0.142 & 4.752 & 0.00 & Signicant \\
\cline { 2 - 8 } & Stakeholder_Trust_y2 & $X_{1} \rightarrow Y_{2}$ & 0.533 & 0.157 & 3.404 & 0.00 & Signicant \\
\cline { 2 - 8 } & UIN_Alauddin_Image_y3 & $X_{1} \rightarrow Y_{3}$ & 0.191 & 0.084 & 2.282 & 0.023 & Signicaant \\
\hline Stakeholder_Satisfaction $\left(Y_{1}\right)$ & Stakeholder_Trust_y2 & $Y_{1} \rightarrow Y_{2}$ & 0.456 & 0.143 & 3.181 & 0.001 & Signicant \\
\cline { 2 - 8 } & UIN_Alauddin_Image_y3 & $Y_{1} \rightarrow Y_{3}$ & 0.151 & 0.074 & 2.025 & 0.043 & Signicant \\
\hline Stakeholder_Trust_ $\left(Y_{2}\right)$ & UIN__lauddin_Image_y3 & $Y_{2} \rightarrow Y_{3}$ & 0.178 & 0.087 & 2.032 & 0.042 & Signicant \\
\hline
\end{tabular}

Source: Amos output, processed 2017

Based on the test results as shown in the above table, it appears that the value of Goodness Of Fit Indices for all criteria in general in the category fit except NFI. Thus the model is said to be overall quite good. According to Wijanto (2007), there are several measures of the fit model in SEM, and the appraisal of model conformity is assessed based on how many model sizes can be satisfied by the research model. The more match target values of the Goodness of Fit measure are met by the model, the better the research model.

Analysis and Testing Structural Models Graduates Quality Impact on Stakeholder Satisfaction, Stakeholder Trust and Image of UIN Alauddin

To facilitate in analyzing the functional relationship between variables then the coefficient value is arranged in Table form as shown in Table 2 below: 
IJBE: Integrated Journal of Business and Economics

e-ISSN: 2549-3280

Table 2. Inter-variable Functional Relationships

\begin{tabular}{|c|c|c|c|c|c|c|c|}
\hline Influencing Variables & Variable Influenced & Direction & Estimation & S.E & T Value & Prob & Information \\
\hline \multirow{3}{*}{ Graduate Quality (X1) } & Stakeholder_Satisfaction_y1 & $\mathrm{X} 1-\mathrm{Y} 1$ & 0.677 & 0.142 & 4.752 & 0.00 & Significant \\
\hline & Stakeholder_Trust_y2 & $\mathrm{X} 1 \rightarrow \mathrm{Y} 2$ & 0.533 & 0.157 & 3.404 & 0.00 & Significant \\
\hline & UIN_Alauddin_Image_y3 & $\mathrm{X} 1 \rightarrow \mathrm{Y} 3$ & 0.191 & 0.084 & 2.282 & 0.023 & Significant \\
\hline \multirow{2}{*}{ Stakeholder_Satisfaction (Y1) } & Stakeholder_Trust_y2 & $\mathrm{Y} 1 \rightarrow \mathrm{Y} 2$ & 0.456 & 0.143 & 3.181 & 0.001 & Significant \\
\hline & UIN_Alauddin_Image_y3 & $\mathrm{Y} 1 \rightarrow \mathrm{Y} 3$ & 0.151 & 0.074 & 2.025 & 0.043 & Significant \\
\hline Stakeholder Trust (Y2) & UIN_Alauddin_Image_y3 & $\mathrm{Y} 2 \rightarrow \mathrm{Y} 3$ & 0.178 & 0.087 & 2.032 & 0.042 & Significant \\
\hline
\end{tabular}

Source: Amos output, processed 2017

1. Influence Quality of graduates $\left(\mathrm{X}_{1}\right)$ on Satisfaction Stakeholder $\left(\mathrm{Y}_{1}\right)$

The coefficient of the influence of graduate quality $\left(\mathrm{X}_{1}\right)$ variable to stakeholder satisfaction $\left(\mathrm{Y}_{1}\right)$ is 0,677 with $t$ value 4,752 with the standard of error 0,145 at significance level 0.000 or under 0.05 . The coefficient shows that the quality of the graduates has a positive and significant impact on stakeholder satisfaction. This means that improving the quality of graduates will be followed by increased stakeholder satisfaction with the assumption that other factors affecting the size of stakeholder satisfaction are considered constant.

2. Influence Quality of graduates $\left(\mathrm{X}_{1}\right)$ on stakeholder trust $\left(\mathrm{Y}_{2}\right)$

The coefficient of the influence of graduate quality variable (X1) on stakeholder trust (Y2) is 0.533 with $t$ value equal to 3.404 with the standard of error 0.157 at significance level 0.000 or below 0.05 . The coefficient shows that the quality variable of graduates has a positive and significant impact on stakeholder trust. This means that improving the quality of graduates will be followed by increasing stakeholder confidence with the assumption that other factors affecting the size of stakeholder confidence are considered constant.

3. Influence Quality of graduates $\left(\mathrm{X}_{1}\right)$ on UIN Alauddin image $\left(\mathrm{Y}_{3}\right)$

The coefficient of the influence of graduate quality variable $\left(\mathrm{X}_{1}\right)$ on UIN Alauddin image $\left(\mathrm{Y}_{3}\right)$ is 0.191 with $\mathrm{t}$ value equal to 2.282 and Error standard (SE) is 0.084 at significance level 0.023 below 0.05 . The coefficient shows that the quality variable of graduates has a positive and significant impact on UIN Alauddin's image. This means that improving the quality of graduates will be followed by the improvement of UIN Alauddin's image with the assumption of other factors that affect the size of the image UIN Alauddin considered constant.

4. The Influence of Stakeholder Satisfaction $\left(\mathrm{Y}_{1}\right)$ on Stakeholder Trust $\left(\mathrm{Y}_{2}\right)$

The coefficient of the influence of Stakeholder Satisfaction variable $\left(\mathrm{Y}_{1}\right)$ to stakeholder trust $\left(\mathrm{Y}_{2}\right)$ is 0.456 with $\mathrm{t}$ value equal to 3.181 and standard of error 0.143 at significance level 0.001 below 0.05 . The coefficient shows that the Stakeholder Satisfaction variable has a positive effect on stakeholder trust. This means that increased Stakeholder Satisfaction will be followed by increased stakeholder confidence with the assumption that other factors affecting the size of the stakeholder trust are considered constant.

5. The Effect of Stakeholder Satisfaction $\left(\mathrm{Y}_{1}\right)$ on UIN Alauddin Image $\left(\mathrm{Y}_{3}\right)$

The coefficient of the influence of Stakeholder Satisfaction variable $\left(\mathrm{Y}_{1}\right)$ to UIN Alauddin image $\left(\mathrm{Y}_{3}\right)$ is 0.151 with $\mathrm{t}$ value equal to 2.025 and Error standard (SE) is 0.074 at significance level 0.043 below 0.05. The coefficient shows that Stakeholder Satisfaction variable has the positive and significant effect on UIN Alauddin's Image. This means that the increase in Stakeholder 
Satisfaction will be followed by the improvement of UIN Alaudin's image with the assumption of other factors that affect the size of the image UIN Alauddin considered constant.

6. The Influence of Stakeholder Trust ( $\left.\mathrm{Y}_{2}\right)$ Against UIN Image Alauddin ( $\left.\mathrm{Y}_{3}\right)$

The coefficient of the influence of stakeholder trust $\left(\mathrm{Y}_{2}\right)$ toward UIN Alauddin $\left(\mathrm{Y}_{3}\right)$ image is 0.178 with $t$ value equal to 2.032 and Error standard (SE) is 0.087 at 0.042 below 0.05 . The coefficient shows that the stakeholder trust variable positively influences the image of UIN Alauddin. This means that the increase of stakeholder trust will be followed by the improvement of UIN Alauddin's image with the assumption of other factors that affect the size of the image UIN Alauddin is considered constant.

The influence of variables in the form of the scheme is shown in the following figure:

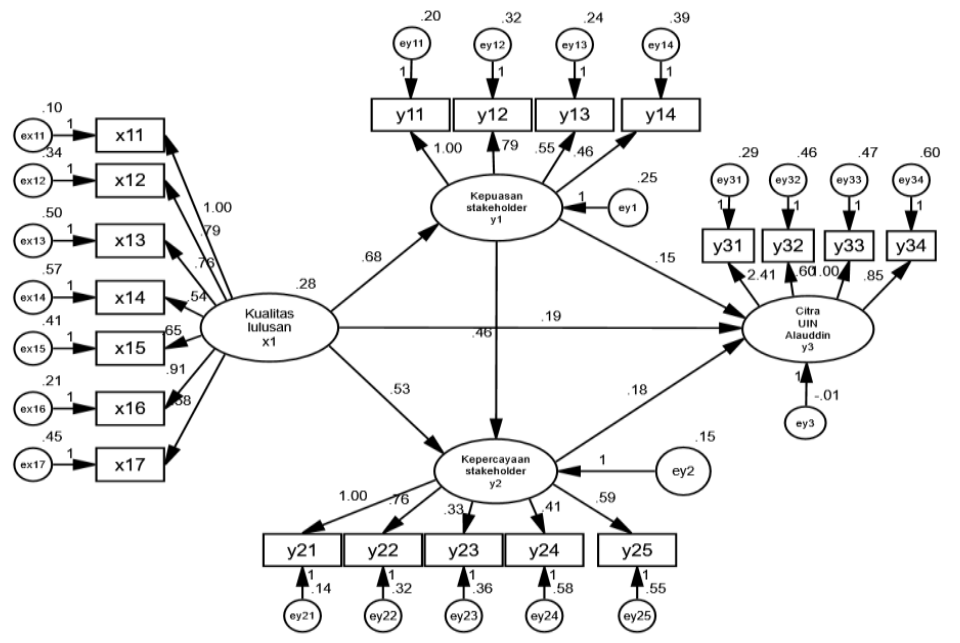

Figure 2. Estimated Results in Scheme

\section{Indirect Effect of Graduates Quality on UIN Alauddin's Image through Stakeholder Satisfaction and Stakeholder Trust}

Based on the results of the scheme as presented in Figure 2, indirect effect, exogenous variables, namely the quality of graduates to the image of UIN Alauddin through stakeholder satisfaction and stakeholder trust as can be seen in Table 3 below:

Table 3. Indirect Effect of Graduates' Quality on UIN Alauddin Image through Stakeholder Satisfaction and Stakeholder Trust

\begin{tabular}{|l|c|}
\hline \multicolumn{1}{|c|}{ Information } & Value \\
\hline $\begin{array}{l}\text { The indirect effect of graduate quality }\left(\mathrm{X}_{1}\right) \text { on stakeholder trust }\left(\mathrm{Y}_{2}\right) \text { through } \\
\text { stakeholder satisfaction }\left(\mathrm{Y}_{1}\right)\end{array}$ & 0.309 \\
\hline $\begin{array}{l}\text { The indirect effect of graduate quality }\left(\mathrm{X}_{1}\right) \text { on UIN Alauddin image through } \\
\text { stakeholder trust }\left(\mathrm{Y}_{2}\right) \text { and stakeholder satisfaction }\left(\mathrm{Y}_{1}\right)\end{array}$ & 0.251 \\
\hline
\end{tabular}

Source: Amos output, processed 2017

Based on Table 3 above, it can be interpreted as follows: 
1. The indirect effect of graduate quality $\left(\mathrm{X}_{1}\right)$ on stakeholder trust $\left(\mathrm{Y}_{2}\right)$ through stakeholder satisfaction $\left(\mathrm{Y}_{1}\right)$ is 0.309 . This indicates that as graduate quality improves the stakeholder trust will increase stakeholder satisfaction by 0.309 .

2. The indirect effect of the quality of graduates $\left(\mathrm{X}_{1}\right)$ on UIN Alauddin's image through stakeholder trust $\left(\mathrm{Y}_{2}\right)$ and stakeholder satisfaction $\left(\mathrm{Y}_{1}\right)$ is 0.251 This indicates that when the quality of graduates improves will increase stakeholder satisfaction and trust so that ultimately will increase the image of UIN Alauddin of 0.251 .

The Effect of Total Quality of Graduates on Stakeholder Satisfaction, Stakeholder Trust, and Image UIN Alauddin

Based on the results of the scheme as presented in Figure 2, obtained the total effect, the exogenous variables, namely the quality of graduates to stakeholder satisfaction, stakeholder trust and the image of UIN Alauddin as can be seen in Table 4 below:

Table 4. Influence of Total Quality of Graduates on Stakeholder Satisfaction, Stakeholder Trust, and Image UIN Alauddin

\begin{tabular}{|l|l|}
\hline \multicolumn{1}{|c|}{ Information } & Value \\
\hline The effect of the total quality of graduates on stakeholder satisfaction & 0.677 \\
\hline The effect of the total quality of graduates on stakeholder trust & 0.842 \\
\hline The effect of the total quality of the graduates on the image & 0.443 \\
\hline
\end{tabular}

Source: Amos output, processed 2017

Based on Table 4 above, it can be interpreted as follows:

1. The effect of the total quality of graduates $\left(\mathrm{X}_{1}\right)$ on stakeholder satisfaction $\left(\mathrm{Y}_{2}\right)$ is 0.677

2. The effect of the total quality of graduates $\left(\mathrm{X}_{1}\right)$ on stakeholder trust $\left(\mathrm{Y}_{2}\right)$ is 0.842

3. The effect of the total quality of graduates $\left(\mathrm{X}_{1}\right)$ on the image of UIN Alauddin $\left(\mathrm{Y}_{3}\right)$ is 0.443

\section{Discussion}

1. The influence of graduates quality on stakeholder satisfaction

Graduates quality variables have a positive and significant impact on stakeholder satisfaction. This means that improving the quality of graduates will be followed by increased stakeholder satisfaction with the assumption that other factors affecting the size of stakeholder satisfaction are considered constant. This result is in line with Musmini (2013) which states that the level of alumni user satisfaction on the quality of education is seen from the ability of graduates or alumni in the world of work. This research is also in line with Idris (2005), which states that with the quality of school graduates (output), it can be explained that the output of the school is said to be of high quality, if the achievement of the school, especially the students' achievement, shows a high achievement in academic achievement. Factors that affect the quality of graduates are the characteristics of education taught by educators, the scoring system used, the curricula provided, and the cooperation of schools with the business world that is suitable to be applied to the learning of vocational subjects

Quality education in the development of a nation can be said to be a necessity. Quality education can give birth to qualified and competitive human resources to ensure quality development process (Sauri S, 2010). Quality education in Indonesia is one of the goals of national development to educate the nation. In addition, it is also contained in the Law of the Republic of Indonesia Number 20 of 2003 on the National Education System, which explains that the 
national education system should be able to ensure equal distribution of educational opportunities, quality improvement and relevance and efficiency of education management to face challenges in accordance with the challenges of changing local life, national, and global so that the need for renewal education in a manner, directed and sustainable. The vision of Indonesian national education is the realization of the national education system as a strong and authoritative social institution to empower all Indonesian citizens to develop into qualified human beings to be able and proactive to answer the challenges of the ever-changing era (Sauri S, 2010; Sardiman, 2010).

The State also regulates in the Decree of the Minister of Administrative Reform of the State Number: KEP / 25 / M.PAN / 2/2004 on General Guidelines for Compilation of Public Satisfaction Index of Service Unit of Government Institution to accommodate service user satisfaction within Government Service Unit (KepMenPan, 2004). The world of education, as one form of service in society, can also apply the above principles. Measurement of the extent to which educational institutions can meet customer expectations can be used as a starting point to determine the quality of educational services of an educational institution (Indahwati, 2008). This is realized through measuring the level of satisfaction of education service stakeholders.

Stakeholders are associated with several parties namely the internal and the external. Internal parties are organizational stakeholders, i.e., employees of managers and non-managers. External parties consist of organizational owners and funders of the organization and most of all our customers.

2. The influence of graduate quality on stakeholder trust

Graduate Quality variables have a positive and significant impact on stakeholder trust. This means that improving the quality of graduates will be followed by increasing stakeholder confidence with the assumption that other factors affecting the size of stakeholder confidence are considered constant. This research is also in line with Idris (2005), which states that with the quality of school graduates (output), it can be explained that the output of the school is said to be of high quality, if the achievement of the school, especially the students' achievement, shows a high achievement in academic achievement. Factors that affect the quality of graduates are the characteristics of education taught by educators, the scoring system used, the curricula provided, and the cooperation of schools with the business world that is suitable to be applied to the learning of vocational subjects.

A stakeholder is an individual, a group of people, community or community both overall and partially that have relationships and interests of the company. Individuals, groups, and communities and communities can be regarded as stakeholders if have characteristics as revealed by Budimanta et al. (in Ghozali and Chariri, 2007) that has the power, legitimacy, and interests of the company.

Nowadays, with many institutions graduating alumni with the same study program, it is easy for the stakeholders to select and select the alumni who are employed, so that the institution must be extra hard to design the various aspects for the alumni to give satisfaction to the stakeholders in which they work. According to Evans and Lindsay (2002), satisfaction is meeting or exceeding customer satisfaction begins with hiring the right person. Customer satisfaction can only be 


\section{IJBE: Integrated Journal of Business and Economics}

e-ISSN: 2549-3280

achieved if the company hires the right people. Another opinion Customer Satisfaction is the feeling of pleasure or disappointment of a person after comparing the performance or results felt compared to expectations (Kotler and Keller, 2007).

Quality assurance system states that one of the indicators that can be used to measure the quality of a product or service is the ability of the product/service in meeting the criteria set by the stakeholders. According to Lasmawan (2010), the quality developed must be proactive which means that the graduates produced by universities can continually adjust to the development of science and technology as well as the socio-cultural realities of the society that continues to grow dynamically.

3. The influence of graduate quality on UIN Alauddin image

Graduate Quality variables have a positive and significant impact on UIN Alauddin's Image. This means that improving the quality of graduates will be followed by the improvement of UIN Alauddin's image with the assumption of other factors that affect the size of the image UIN Alauddin considered constant.

Yavas and Shemwell (1996), Landrum et al. (1998) and Parameswaran and Glowacka (1995) in Dirgantari (2012) found that higher education institutions need to maintain or develop different images to create competitive advantage in an increasingly competitive market.

4. The influence of stakeholder satisfaction on stakeholder trust

Stakeholder Satisfaction Variables have a positive effect on stakeholder trust. This means that increased Stakeholder Satisfaction will be followed by increased stakeholder confidence with the assumption that other factors affecting the size of the stakeholder trust are considered constant. These results are in line with Nugroho (2010) at one of Jakarta's leading private universities, concluding that satisfaction has a positive impact on image and loyalty.

5. The influence of stakeholder satisfaction on UIN Alauddin image

The coefficient shows that Stakeholder Satisfaction variable has the positive and significant effect on UIN Alauddin Image. This means that the increase of Stakeholder Satisfaction will be followed by the improvement of UIN Alauddin with the assumption of other factors that affect the size of the image UIN Alauddin is considered constant. These results are in line with Irawan (2010) describes customer satisfaction is determined by the perception of customers for the performance of products or services in meeting customer expectations. Customers are said to be satisfied when the performance of a product or service by what is perceived by the customer and by the expected and vice versa.

Also, Kotler (2011) also adds satisfaction is the feeling of pleasure or disappointment of someone who emerged after comparing the performance (result) of the product thought to the expected performance (result). With the high satisfaction and customer loyalty to a product and services offered by the company will be able to create a good image for the company for the development of market share and corporate life in a long time, Corporate image is the image of an organization as a whole, can be concluded the image is not only judged from the product or service produced but the image of a company that is perceived by the customer, Kotler (2011) 
also added the image of the company is also defined as the way people perceive or think of a company that there dibenak customers.

5. The Influence of Stakeholder Trust on UIN Alauddin Image

The stakeholder trust variable positively influences the image of UIN Alauddin. This means that the increase of stakeholder trust will be followed by the improvement of UIN Alauddin image with the assumption of other factors that affect the size of the image UIN Alauddin is considered constant.

Trust is an individual attitude that refers to consumer confidence in the quality and reliability of the services it receives (Garbarino and Johnson in Kusmayadi, 2007). According to David A. Aaker (2004), customer confidence in the company is an important attribute in developing a company. An institution will be credible if it can provide benefits to its graduate user stakeholders as well as good behaviour from its employees. Consumer belief (Consumer Beliefs) is all the knowledge possessed by consumers and all consumer conclusions about objects, attributes, and benefits (Mowen and Minor, 2002).

a) Objects can be products, people, companies, and everything where someone has trust and attitude.

b) Attributes are characteristics or features that may or may not be owned by objects.

c) Benefits are positive results given attributes to consumers.

According to Gurviez and Korchia (2003), several things can be identified from the variables of trust. First, trust and commitment are the most important and strategic variables to maintain longterm relationships with industry partners and businesses. Second, the explanation of the variable of trust and commitment in the relationship between the company and the consumer, gives supplements on economic theory, especially about transaction costs. Third, the greatest difficulty in conceptualizing trust is on cognitive and affective grounds. Some factors such as the brand, past experience and so on can affect consumer confidence.

\section{Conclusion and Suggestion}

\section{Conclusion}

Based on the discussion that has been described in the previous chapter, it can be concluded as follows:

1. The quality of UIN Alauddin Makassar graduates has a positive and significant impact on stakeholder satisfaction, stakeholder trust and image of UIN Alauddin Makassar. This indicates that the quality of UIN Alauddin Makassar graduate has been able to influence stakeholder satisfaction, stakeholder trust and image of UIN Alauddin Makassar.

2. Stakeholder satisfaction has a positive and significant impact on stakeholder trust and image of UIN Alauddin Makassar. This indicates that stakeholder satisfaction has been able to influence stakeholder trust and image of UIN Alauddin Makassar.

3. The stakeholder trust has a positive and significant impact on the image of UIN Alauddin Makassar. This indicates that stakeholder trust has been able to influence the image of UIN Alauddin Makassar.

\section{Suggestions}


Based on the discussion that has been recounted in the previous chapter, detailed suggestions can be put forward for both knowledge development and practical purposes. The research suggestions are described as follows:

1. UIN Alauddin Makassar needs to improve the quality factor of alumni of UIN Alauddin, stakeholder satisfaction and stakeholder trust which become important factors that directly influence the image of UIN Alauddin Makassar. Therefore, improving the quality of UIN Alauddin graduates, stakeholder satisfaction and stakeholder trust on UIN Alauddin Makassar image is a priority of UIN Alauddin Makassar.

2. This research takes the object of research that is UIN Alauddin Makassar. Thus the conclusions obtained in this study certainly not possible to be made conclusions accepted if applied to other objects outside the object of this study.

\section{References}

1) Aaker, D. A. (2004). Manajemen Ekuitas Merek. Terjamahan Aris Ananda. Jakarta: Mitra Utama.

2) Alma, B. (2007). Manajemen Pemasaran dan Pemasaran Jasa. Edisi Revisi. Bandung: CV. Alfabeta.

3) Amin, et al.,. (2013). Contrasting the Drivers of Customer Satisfaction on Image, Trust, and loyalty of Muslim and Non-Muslim Customers in Malaysia. International Journal of Bank Marketing, (31)2, pp.79-97.

4) Aydin, S. and Ozer, G. (2005). National Customer Satisfaction Indices: A Implementation in the Turkish Mobile Telephone Market. Marketing Intelligence \& Planning, (23)5.

5) Bowden, Jana L. H., Tracey S. D., and Greg, E. (2009). The Role of Relational Antecedents and the Effect of Experience in the Development of Service Loyalty. ANZMAC

6) Chariri dan Ghozali, A. (2007). Teori Akuntansi. Yogyakarta: Penerbit Andi.

7) Coyles, Stephanie, and Gokey, Timothy C. (2002). Customer Retention is Not Enough. The McKinsey Quarterly, 2.

8) Crompton, J. L., and C.W. Lamb. (1986). Marketing Government and Social Services. New York: John Willey and Son.

9) Dirgantari, P. D. (2012). Pengaruh Kualitas Layanan Jasa Pendidikan terhadap Kepuasan Mahasiswa Serta Dampaknya terhadap Upaya Peningkatan Citra Perguruan Tinggi Negeri Menuju World Class University (Studi pada Mahasiswa Asing di ITB, UNPAD, dan UPI). Didapatkan pada ejournal.upi.edu/index.php/mdb/article/view/ 1039.

10) Evans, J. R. and William M. L. (2002). The Management and Control of Quality. 5 the ed. Ohio: South-Western.

11) Gurviez, Patricia dan Korchia, Michael. (2003). Proposal for a Multidimensional Brand Trust Scale. 32nd EMAC-Conference-Glasgow.

12) Irawan, H. (2010). 10 Prinsip Kepuasan Konsumen. PT Elex Media. Komputindo. Jakarta: Sumber Buku.

13) Kotler, P. dan Keller, K. L. (2007). Manajemen Pemasaran. Edisi Kedua Belas. Jilid 1. dialihbahasakan oleh Benjamin Molan. Jakarta: PT Indeks.

14) Kotler, P. (2009). Manajemen Pemasaran. Jakarta: Erlangga.

15) Kusmayadi, T. (2007). Pengaruh Relatinship Quality terhadap Loyalitas Nasabah Tabungan., Jepara: STIE STAN Indonesia mandiri.

16) Mowen, J. C. dan Minor, M. (2002). Perilaku Konsumen. Jilid Kedua. Jakarta: Erlangga. 
17) Nugroho, A. (2010). Analisis keterkaitan antara kepuasan proses belajar mengajar, citra, dan loyalitas di Perguruan Tinggi (disertasi). Bogor: Sekolah Pascasarjana, Institut Pertanian Bogor.

18) Nurhayati, R. (2011). Pengaruh Kualitas Produk dan Harga Terhadap Loyalitas Pelanggan. (Skripsi). Yogyakarta: Universitas Pembangunan Nasional Veteran.

19) Buku Prosiding Seminar Nasional Fakultas Ekonomi IX dan IKA - UT UTCC, 11 November 2017 ISSN: 977254107701660

20) O'Brien, P. (2002). Making College Count: A Real World Look at How To Succeed in College. Ten Speed Press.

21) Rahayu. (2009). Strategi meraih keunggulan dalam industri jasa. Bandung: Alfabeta.

22) Setyaningsih, I. \& Abrori, M. (2013). Analisis Kualitas Lulusan Berdasarkan Tingkat Kepuasan Pengguna Lulusan. Jurnal Ilmiah Teknik Industri, (12)1.

23) Tom, Gail and Elmer, L. (1994). Alumni Willingness to Give and Contribution Behaviour. Journal of Services Marketing, (8)4, pp. 57-62. 